\section{Создание мониторинговой формы лесного ГИС-кадастра для прогноза эффективного лесопользования на территории субъекта РФ}

\author{
Р. Н. Ковалев ${ }^{1}$ \\ Е. Н. Щепёткин \\ Уральский государственный лесотехнический \\ университет
}

\begin{abstract}
АННОТАЦИЯ
Решаемая авторами задача: разработка базы знаний для преобразования лесного ГИС-кадастра в мониторинговую форму на основе совмещенного анализа различных слоев географической, лесоводственной и эколого-экономической информации. Основные целевые параметры: мониторинговая форма лесного ГИСкадастра обеспечит формирование экономически обоснованных тарифов всех видов лесных платежей (такс), оценки ущерба природным экосистемам, а также дифференциацию и сбор платежей в бюджеты различных ведомств и уровней (земельные комитеты, рыбное и охотничье хозяйства, лесные ведомства, экологические фонды, бюджеты местного, областного и федерального уровней и др.), прогнозирование эффективного лесопользования на территории субъекта РФ на основе геомониторинга лесных экосистем.
\end{abstract}

Ключевые слова: кадастровая оченка, комплексный территориальный кадастр природных ресурсов, геомониторинг.

\section{SUMMARY}

The task being solved in the project: to work out the knowledge base for transformation of forestry GIS- cadastre into the monitoring form on the base of combined analysis of different layers of geographic, forestry and ecologo-economic information. The main purpose parameters: the monitoring form of forestry GIS-cadastre will ensure the forming of economically valid tariffs of all kinds of forestry payments (tariffs), of damage estimation to natural ecosystems, and also the differentiation and collection of payment into the budgets of different departments and levels (land committees, fish and hunt industries, forestry departments, ecological funds, budget of local, regional and federal levels, etc), the forecast of effective forest use on the territory of Russian Federation Subject on the base of forestry ecosystems geomonitoring.

Keywords: cadastre estimation, complex territorial cadastre of natural resources.

\footnotetext{
${ }^{1}$ Авторы - соответственно профессор и доцент кафедры менеджмента и внешнеэкономической деятельности предприятия
}

(c) Р. Н. Ковалев, Е. Н. Щепёткин, 2003

\section{ПОСТАНОВКА ПРОБЛЕМЫ}

Решения Международных конференций по устойчивому управлению лесами (Хельсинки (1993г.), Женева (1994 г.) и др.) официально обозначили переход лесной науки и практики на концепцию экосистемного лесопользования, основанную на сохранении биоразнообразия лесных экосистем, их генетической, экологической и культурной информации. Основные принципы устойчивого управления лесами официально закреплены в качестве юридической нормы в Лесном кодексе РФ.

В России пока отсутствует практический опыт экосистемного управления лесным комплексом на основе геомониторинга. В теоретическом плане ряд научных организаций вели разработки по данной проблеме, например, Институт леса им. В. Н. Сукачева СО РАН, в рамках пилотного российско-американского проекта «Экосистемное управление бореальными лесами в центральной Сибири». В рамках этого проекта задача разработки методов прогноза эффективного лесопользования в полном объеме не была решена, а проект прекратил свое существование. Другие разработки были еще менее существенны. За рубежом практический опыт устойчивого управления лесами значительно шире ввиду более современных материальной базы и программного обеспечения, но он носит, как правило, эмпирический характер и не имеет прочной теоретической базы.

Смена подходов к лесопользованию, целенаправленное регулирование лесных экосистем требует пересмотра принципов информационного обеспечения лесного хозяйства, расширения его содержания, разработки методологии кадастровой (эколого-экономической) оценки природных экосистем. В наиболее современной и эффективной форме эти принципы могут быть реализованы на базе геоинформационных систем в виде ГИСтехнологий. ГИС дает возможность субъектам лесных отношений оперативно получать информацию в виде топографических карт, диаграмм и таблиц по лесотаксационным, эколого-экономическим и другим показателям. Таким образом, ГИСы являются современной информационной основой кадастра лесных земель и они в наиболее полной форме позволяют отразить лес как важнейший компонент биосферы, объект хозяйственной деятельности человека и возобновляемый источник капитала.

Когда кадастр представляет собой систематизированный свод пространственно-временной информации, базирующейся на топографо-геодезической основе, его можно рассматривать и развивать как геопространственный мониторинг определенного назначения, имеющий экономическую составляющую. Для преобразования ГИСкадастра в мониторинговую форму необходимо дополнить систему соответствующей базой знаний. Мониторинг можно рассматривать как универсальную информационную систему, содержащую подсистемы наблюдений, математической обработки и моделирования, которые обеспечивают прогноз контролируемых процессов с целью эффективного управления ими на основе совмещенного анализа различных слоев географической, эколого-экономической и иной информации. В 
плане лесного кадастра его экономическая составляющая может быть дополнена и развита:

- картами экологического зонирования, оптимально учитывающими средоформирующие функции лесных экосистем;

- моделями оценок направленности лесообразовательных продукционных процессов;

- лесоводственными моделями ведения хозяйства, отражающими биогеоценотические процессы в лесных экосистемах;

- картами текущей пожароустойчивости лесов с детальным пирологическим описанием каждого лесотаксационного выдела для разработки системы повышения пожароустойчивости лесов с учетом экологических условий (рельефа, гидрографии заболоченности и других естественных преград для огня).

Аналогичные модели могут быть созданы для оценок вероятности возникновения очагов насекомыхвредителей, направленности побочных пользований лесом, качества мест обитания диких животных, устойчивости насаждений к неблагоприятным условиям внешней среды (ветровалы, наводнения) и др. Одними из главных достоинств моделей лесного геомониторинга являются объемное видение такого сложного объекта, как лесная экосистема, возможность учета динамики ее развития для выбора научно обоснованной стратегии лесопользования. В данном проекте планируется совместить предлагаемый подход к проблеме кадастровой (экономической) оценки лесов с развитием системы лесного геомониторинга.

\section{СПОСОБЫ РЕШЕНИЯ}

В наиболее современной и эффективной форме вышеуказанные принципы могут быть реализованы на базе геоинформационных систем в виде ГИС-технологий. Базовыми пакетами ГИС-технологий для решения данной задачи являются разработанные в США MapInfo Professional 5/5, MapEDIT и MapBasic.

\section{ОЖИДАЕМЫЕ РЕЗУЛЬТАТЫ}

В результате внедрения данной методики экономической оценки лесов субъекта РФ на базе ГИСтехнологий создаются условия для:

- развития инструментов экономического управления окружающей средой;

- создания экономической основы при определении платежей, податей и такс за использование лесных природных комплексов или их отдельных составляющих;

- эколого-экономического обоснования проектов, экологических экспертиз;

- обоснования эффективности природоохранных мероприятий и др.

Ожидаемый эффект от внедрения данной НИР будет складываться из:

- оценки природных комплексов при смене собственника, сдаче в аренду, концессию и т.п.;

- создания экономической основы при определении платежей, податей и такс за использование природных комплексов или их отдельных составляющих;
- обоснования ущерба, возмещаемого за вред, причиняемый природным комплексам;

- эколого-экономического обоснования проектов, экологических экспертиз;

- развития основы для внедрения комплексного кадастра природных ресурсов и районирования территорий субъектов РФ.

Нормативно-правовая база, разработанная на основе данной НИР, позволит регламентировать финансовые потоки и экономические отношения в системе природопользования: плата за ресурсы соответствующим владельцам и в местные бюджеты, плата за землю в земельные комитеты, плата за загрязнение в экологические фонды, возмещаемый ущерб между различными участниками природопользования и т.д. Если исходить из того, что, например, общая стоимость запасов природного капитала только Ярославской области на конец 1996 г. составляла, по данным независимой оценки, 31,5 трлн руб. (6,3 млрд долларов США), то сумма получаемого бюджетного и народнохозяйственного эффекта будет выражаться в сопоставимых цифрах.

Лесной кадастр на базе ГИС-технологий, куда в качестве его составной части входит эколого-экономическая оценка земель лесного фонда субъекта РФ, позволит обеспечить государственные и муниципальные органы, юридические и физические лица достоверной информацией о ценности конкретных участков лесных земель, об условиях и формах их эффективного использования. Он позволит обеспечить формирование экономически обоснованных тарифов всех видов лесных платежей (такс), оценки ущерба природным экосистемам, а также дифференциацию и сбор платежей в бюджеты различных ведомств и уровней (земельные комитеты, рыбное и охотничье хозяйства, лесные ведомства, экологические фонды, бюджеты местного, областного и федерального уровней и др.). Пока подобной системы лесного кадастра, доведенной до практической реализации, в России и за рубежом не существует.

Включение кадастровой (эколого-экономической) оценки в систему экосистемного устойчивого управления лесами на федеральном, региональном и местном уровнях управления позволит:

- экономически оценить имеющиеся на территории субъекта РФ леса и уровень их использования;

- установить роль лесных активов в формировании и направлении денежных потоков в экономике данной территории;

- выполнить анализ движения денежных потоков в системе "окружающая среда - экономика - окружающая среда" и оценку уровня и темпов истощения лесных активов территорий, потери ими капитала устойчивости. 